International Journal of Agriculture, Environment and Bioresearch

Vol. 06, No. 06; 2021

ISSN: $2456-8643$

\title{
COMPARISON BETWEEN TEMPERATURE DATA OBTAINED FROM AN AUTOMATED WEATHER STATION AND A DIGITAL SENSOR LOCATED WITHIN THE CROP
}

\author{
TORRES-CRUZ María Monserrat, FUENTES-DÁVILA Guillermo, and FÉLIX-VALENCIA Pedro \\ Inifap, Campo Experimental Valle Del Yaqui ,apdo. Postal 155, Km 12 Norman E. Borlaug, Entre 800 Y 900, Valle \\ Del Yaqui, Cd. Obregón, Sonora, México Cp 85000 \\ https://doi.org/10.35410/IJAEB.2021.5683
}

\begin{abstract}
Weather conditions in agriculture are determinants due to their effects on plants. Depending on the species, they will have values or adequate ranges within which their physiological functioning will be optimum; however, if weather or climatic conditions are outside these ideal range, their growth and development will be affected. The objective was to compare temperature records obtained from the weather station Block 910-CIANO and those obtained from the digital sensor datalogger LCD-520, located within a wheat plot at the Norman E. Borlaug Experimental Station in Sonora, Mexico. The sensor was set up to record hourly air temperature data, and data were obtained from the automated weather station network which was closest to the plot were the sensor was located; data comprise the wheat season fall-winter 2019-2020, from February 4 to May 5, 2020. Data were filtered into daily and night schedule, considering the time from 7:00 to 18:00, and from 19:00 to 6:00. The t-students was performed in order to determine mean significant differences between the datalogger and the weather station (WS). The results indicated significant mean differences between both instruments. The minimum temperature recorded by the datalogger was $1.2^{\circ} \mathrm{C}$ and $0.76^{\circ} \mathrm{C}$ below the range shown by the WS, while the maximum temperature recorded by the datalogger was $1.42^{\circ} \mathrm{C}$ and $5.39^{\circ} \mathrm{C}$ above the range shown by the WS. The overall average temperature recorded by the datalogger was $0.44^{\circ} \mathrm{C}$ higher than the WS, and it also recorded 122 more cold units more than the WS.
\end{abstract}

Keywords: Air temperature, weather station, datalogger, wheat.

\section{INTRODUCTION}

Weather conditions in agriculture are determinants due to their effects on plants. Depending on the species, they will have values or adequate ranges within which their physiological functioning will be optimum; however, if weather or climatic conditions are outside these ideal range, their growth and development will be affected [1]. Therefore, it is important to monitor the climatic variables, so that the farmer may know when and how to produce a crop according to the climate, following a prediction model for the phenology of a crop, pests, and diseases [2]. There are different tools or electronic instruments from which it is possible to obtain weather data, such as the combination of sensor/data recorder (dataloggers) which are economically feasible, and seem to be precise enough to unfold into measurements matrix to solve the local atmospheric structure during periods of weeks or months [3]. Dataloggers are autonomous devices which can read a diverse type of signals (temperature, relative humidity, barometric pressure, height pressure, dew point, acceleration), and store data in the internal memory in order to be discharged later on into a computer [4]. Weather data can also be obtained from automated 
Vol. 06, No. 06; 2021

ISSN: $2456-8643$

weather stations (AWS) which are electronic devices with autonomous energy, that measures and records weather conditions through electronic sensors [5]. In the state of Sonora, Mexico, there are 113 weather stations (WS) which comprise the automated weather station network of Sonora (REMAS), which have the objectives of generating, storing, processing, and disseminating weather data in the state. REMAS WS record data every $10 \mathrm{~min}$ and also provide integrated data by the hour and day; therefore, air temperature can be evaluated (minimum and maximum), relative humidity, rainfall, solar radiation, direction and wind speed, barometric pressure, and evapotranspiration [6]. The dissemination of the weather data is esential for the agricultural sector, since it constitutes a highly useful tool in the decisión-making process for the best agricultural management of crops, and because climatic conditions can not be managed directly. However, as climatic conditions are measured and recorded by sensors and WS, the farmer may take preventive or adjust activities in order to protect the crop from adverse climatic conditions or to take advantage of the good ones [7]. Information about weather is also very useful for analysis of current conditions, preparation of forecasts and alerts, agroclimatic studies, preparation of operations dependent of the weather, like construction activities, aerodromes [810], application in thematic associated to hydrology or agronomy, specifically frost alert systems and pests, as well as in flood of rivers [11,12]. The objective of this work was to gather and analyze weather data obtained from the weather station Block 910-CIANO and from the sensor datalogger LCD-520 within a wheat plot at the Norman E. Borlaug Experimental Station, and to make comparison between the information provided by the two devices.

\section{MATERIALS AND METHODS}

Climatic data were recorded within the wheat crop with wireless sensors LCD-520 (dataloggers, Measurement Computing Corporation), at the Norman E. Borlaug Experimental Station which belongs to the National Institute for Forestry, Agriculture, and Livestock Research (INIFAP), located in Block $910\left(27^{\circ} 22^{\prime} 3.01^{\prime \prime} \mathrm{N}\right.$ and $109^{\circ} 55^{\prime} 40.22^{\prime \prime} \mathrm{W}, 37$ masl) of the Yaqui Valley in the state of Sonora, Mexico. The sensor was set up to record hourly air temperature data. Also, data were obtained from the automated WS network in Sonora (REMAS) which was closest to the plot were the sensor was located with the objective to compare the data obtained from both sources. Data set comprises the wheat season fall-winter 2019-2020, from February 4 to May 5, 2020. The average temperature from the sensor and from the WS were calculated, taking into consideration the maximum and minimum temperatures as well as the cold units. Data were captured in Excel with the daily and hourly records. Data were also filtered into daily (7:00 to 18:00) and nightly (19:00 to 06:00) schedules. The t-student test was applied in order to test if there were significant mean differences between data from the datalogger and the WS.

\section{RESULTS AND DISCUSSION}

The t-student test detected significant statistical differences the mean hourly temperature between the datalogger and the WS Block $910(\mathrm{t}=1.89, \mathrm{p}>0.05)$. The calculated standar deviation, variance, and coefficient of variation of the temperature (Table 1) showed greater dispersion in the datalogger than in the WS. 
Table 1. Statistical summary for the air temperature recorded by the datalogger and the weather station Block 910-CIANO.

\begin{tabular}{|c|c|c|c|}
\hline Stadistical & Datalogger & $\begin{array}{l}\text { Weather } \\
\text { Block } \\
\text { CIANO }\end{array}$ & $\begin{array}{r}\text { station } \\
910-\end{array}$ \\
\hline $\mathrm{N}$ & 2161 & 2161 & \\
\hline Minimum & -0.017 & 1.04 & \\
\hline Maximum & 41.75 & 36.36 & \\
\hline Mean & 19.27 & 18.83 & \\
\hline Standard deviation & 8.42 & 6.78 & \\
\hline Variance & 70.86 & 45.94 & \\
\hline $\begin{array}{l}\text { Coefficient } \\
\text { variation }\end{array}$ & $44 \%$ & $36 \%$ & \\
\hline Statistical t & 1.89 & & \\
\hline $\mathrm{P}(\mathrm{T}<=\mathrm{t})$ two tails & 0.06 & & \\
\hline $\begin{array}{l}t \text { critical value (two } \\
\text { tails) }\end{array}$ & 1.96 & & \\
\hline
\end{tabular}

The minimum temperature recorded by the datalogger located within the wheat plot oscillated between $-0.17^{\circ} \mathrm{C}$ and $17.33^{\circ} \mathrm{C}$ (Fig. 1) with an average temperature of $9.69^{\circ} \mathrm{C}$ while in the WS it oscillated between $1.04^{\circ} \mathrm{C}$ and $18.09^{\circ} \mathrm{C}$ with an average temperature of $11.14^{\circ} \mathrm{C}$. The maximum temperature recorded by the datalogger located within the wheat plot oscillated between $18.33^{\circ} \mathrm{C}$ and $41.75^{\circ} \mathrm{C}$ (Fig. 2) with an average temperature of $30.26^{\circ} \mathrm{C}$ while in the WS it oscillated between $16.91{ }^{\circ} \mathrm{C}$ and $36.36{ }^{\circ} \mathrm{C}$ with an average temperature of $27.67^{\circ} \mathrm{C}$. The overall average temperature recorded by the datalogger located within the wheat plot oscillated between $10.51^{\circ} \mathrm{C}$ and $27.21^{\circ} \mathrm{C}$ (Fig. 3) with an average temperature of $19.27^{\circ} \mathrm{C}$ while in the WS it oscillated between $10.33^{\circ} \mathrm{C}$ and $26.10^{\circ} \mathrm{C}$ with an average temperature of $18.83^{\circ} \mathrm{C}$.

Cold units recorded by the datalogger were 306 while the WS recorded 184 (Fig. 4). It can be observed that the accumulation of cold units recorded by the datalogger started to be more consistent by the middle of February. On February 15 there was a difference of 14 cold units between the sensor and the WS, which with time it became larger, 37 on February 29, 49 on March 15, 70 on March 31, 101 on April 15, 122 on April 30 and on May 5. Heat waves ocurred during the season; from February 18 to 24 there was a short heat wave, and a shorter one on February 28 to March 2. 


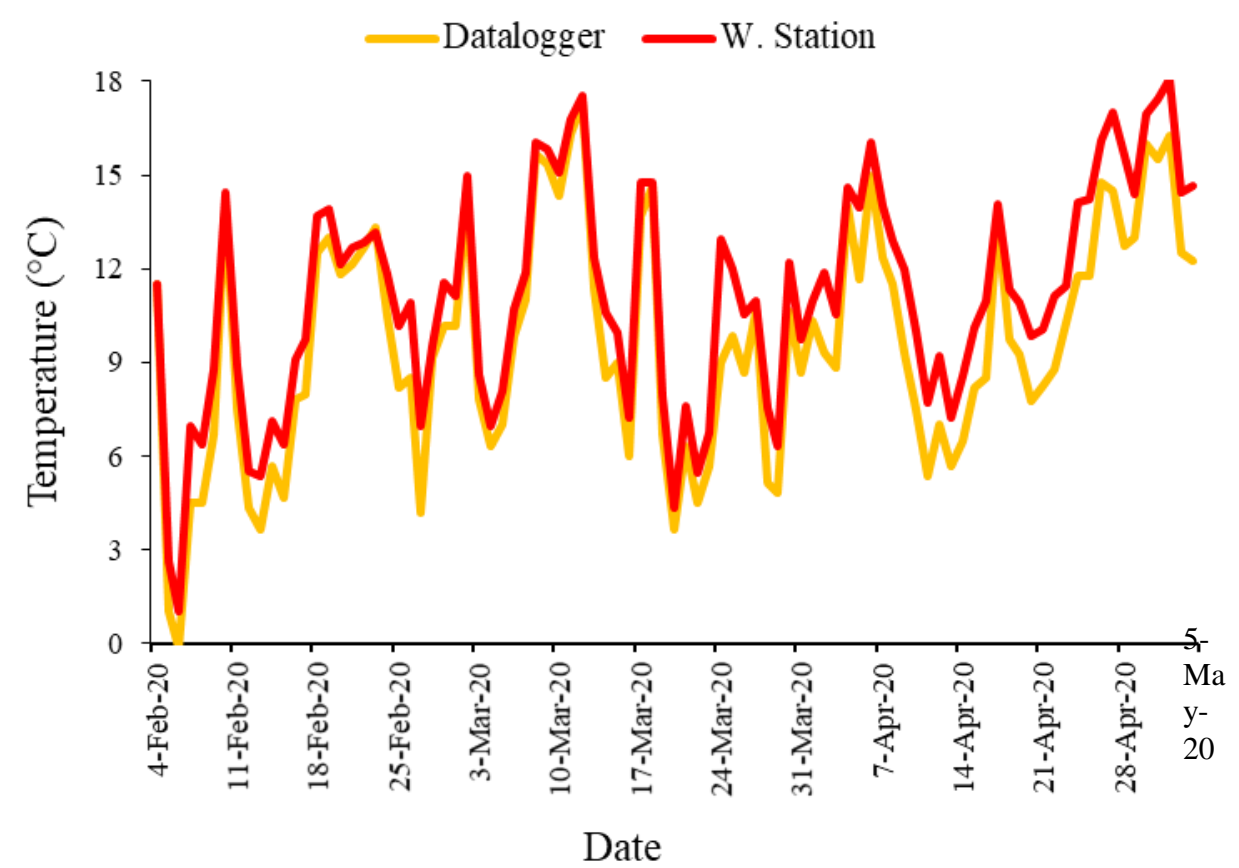

Figure 1. Minimum temperature recorded by the datalogger LCD-520 and the weather station Block 910-CIANO from February 4 to May 5, 2020, at the Norman E. Borlaug Experimental Station in the Yaqui Valley, Sonora, Mexico.

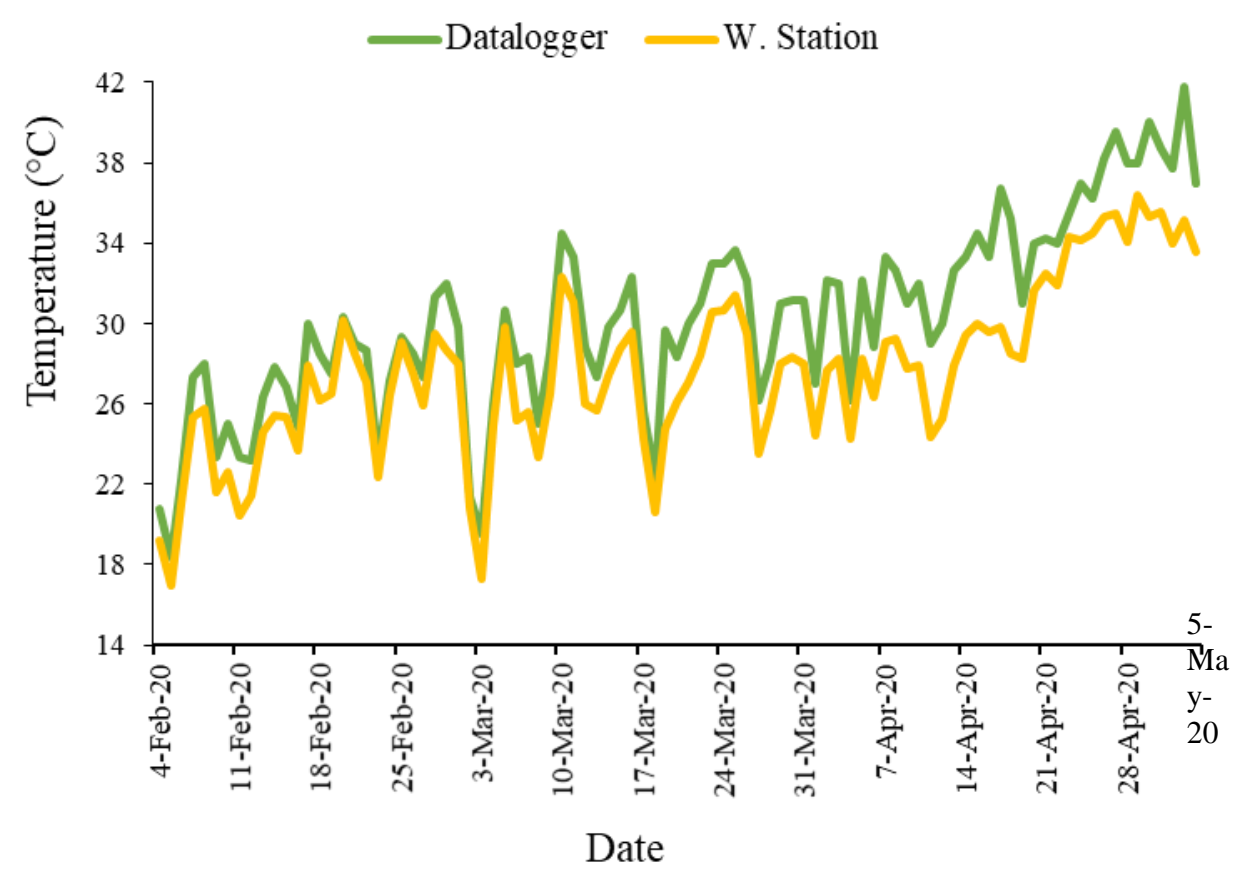


Vol. 06, No. 06; 2021

ISSN: $2456-8643$

Figure 2. Maximum temperature recorded by the datalogger LCD-520 and the weather station Block 910-CIANO from February 4 to May 5, 2020, at the Norman E. Borlaug Experimental Station in the Yaqui Valley, Sonora, Mexico.

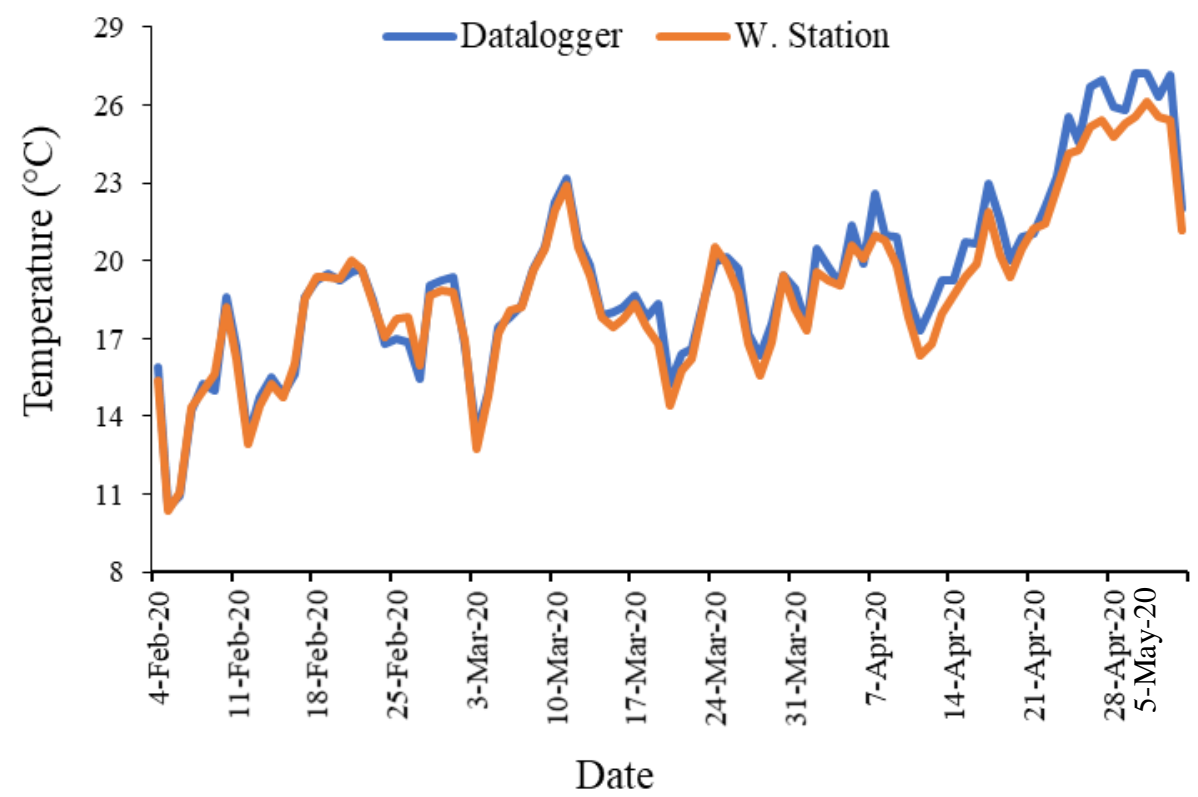

Figure 3. Average temperature recorded by the datalogger LCD-520 and the weather station Block 910-CIANO from February 4 to May 5, 2020, at the Norman E. Borlaug Experimental Station in the Yaqui Valley, Sonora, Mexico.

In March, the first heat wave occurred from the 6th to the 15th and no cold units were recorded, then, the second took place on March 17 and 18. The third heat wave recorded by the station occurred from March 24 to 27 while the sensor did not recorded cold units on March 27 and 30. The next heat wave recorded by the station occurred from April 1 to 9, while the sensor detected a heat wave from April 4 to 8. From April 15 to May 5 the WS only recorded one cold unit on April 20, while the sensor recorded 4 cold units on April 16, 2 on April 18, 1 on April 19, 6 on April 20, 6 on April 21, and 3 on April 22.

Temperatures recorded at the crop level are different than those recorded by the WS which is positioned at $3 \mathrm{mt}$ above the soil level. The crop canopy might induce an effect on the sensor so that the temperature is different and it has a greater impact on development of the plant. Another aspect of interest is the hourly average temperatures (Fig. 5), where it can be observed that the difference in temperature recorded by the datalogger located within the wheat plot, indicates that the WS during the day is $1.89^{\circ} \mathrm{C}$ in average lower than the datalogger, while at night, the datalogger records colder temperatures, that is, an average of $-0.98^{\circ} \mathrm{C}$ lower than the records of the WS.

It appears that the location is the key factor that causes the value differences in temperature measurements from each instrument. The datalogger is located within the wheat plot where irrigation might have an important effect, as well as plant development, while the WS on top of a 
concrete platform at the soil level, and additionally $1 \mathrm{~km}$ away from the wheat plot; therefore, the absorption properties and heat radiation are different in both scenarios. In 2005, several studies were conducted by the National Weather Service of the United States, where they found that the differences between the temperatures recorded by sensors with different technologies could be relevant [13].

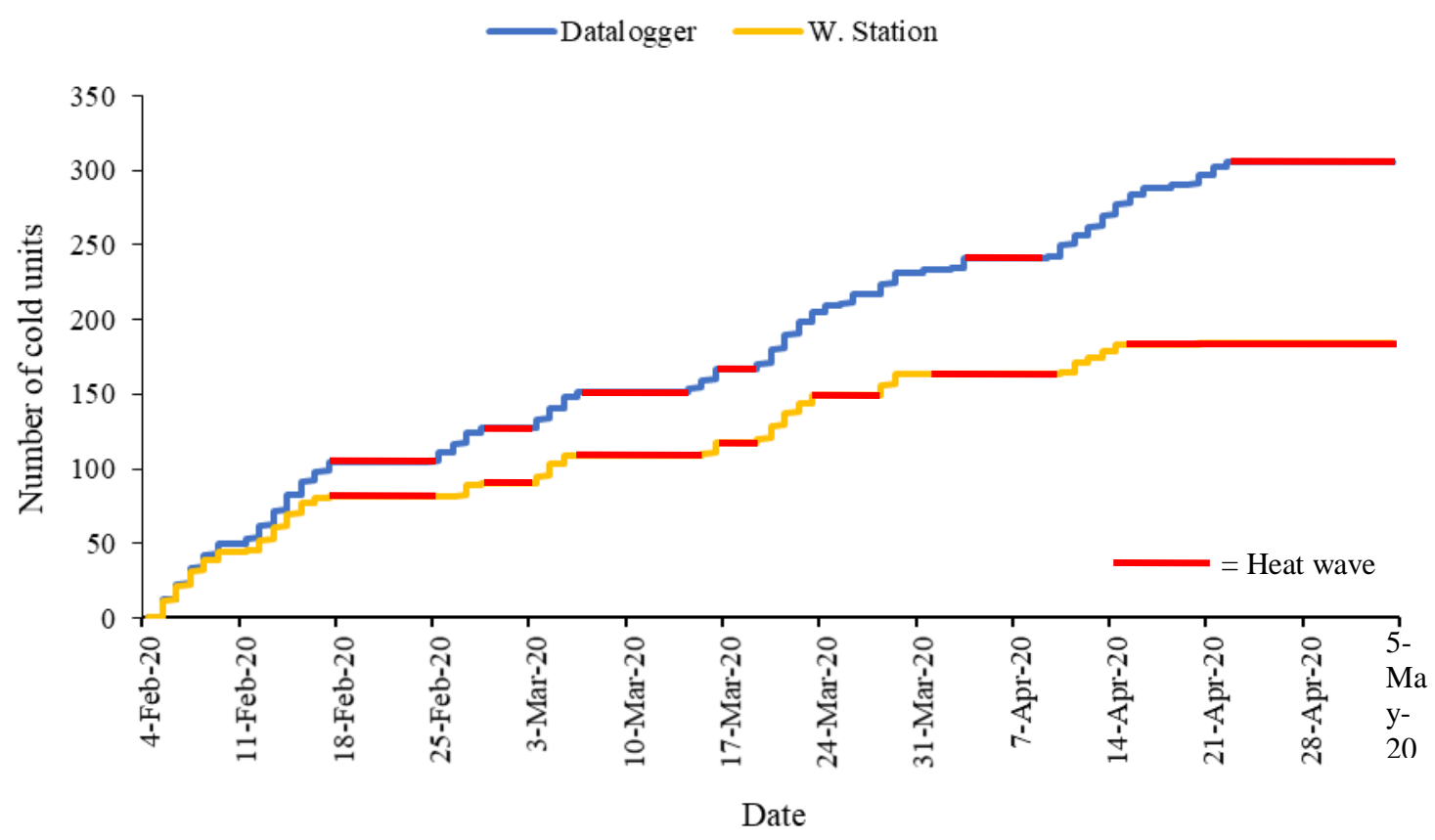

Figure 4. Accumulated cold units recorded by the datalogger LCD-520 and the weather station Block 910-CIANO from February 4 to May 5, 2020, at the Norman E. Borlaug Experimental Station in the Yaqui Valley, Sonora, Mexico.

Gattinoni et al. [14] compared the quality of data gathered daily and monthly of temperature and precipitacion during the year 2007, between three WS simultaneously (one conventional and two automated) at daily and monthly scales; the statistical parameters, specially temperature, resulted to be similar between the stations, but the annual cumulative values and extremes of precipitation showed greater differences.

Peña Quiñones et al. [15] quantified the difference between the air temperature (AT) measured at a standard WS and the AT within a six-year-old vineyard, by installing thermistors and thermocouples within the vine canopy at heights of $0.5 \mathrm{~m}$ and $1.2 \mathrm{~m}$ above the soil surface and adjacent to the berry clusters. In the middle of the clusters sensors were installed to determine the AT surrounding the clusters facing east and west. The data were recorded within the canopy from December 2015 to June 2017 as well as at the standard WS that was installed close to the vineyard $(410 \mathrm{~m})$. Significant differences were found between the AT measured at the WS and those within the vineyard during the summer, when the average daily minimum AT within the 
canopy was $1.2^{\circ} \mathrm{C}$ less than at the WS, and the average daily maximum AT in the canopy was $2.0^{\circ} \mathrm{C}$ higher than at the WS. The mean maximum AT measured in the clusters facing east was $1.5^{\circ} \mathrm{C}$ higher and west $4.0^{\circ} \mathrm{C}$ higher than the temperature measured at the WS. They concluded that models that assume that AT measured at a WS is similar to AT measured in the vineyard canopy, could have greater uncertainty than models that consider the temperature within the canopy.

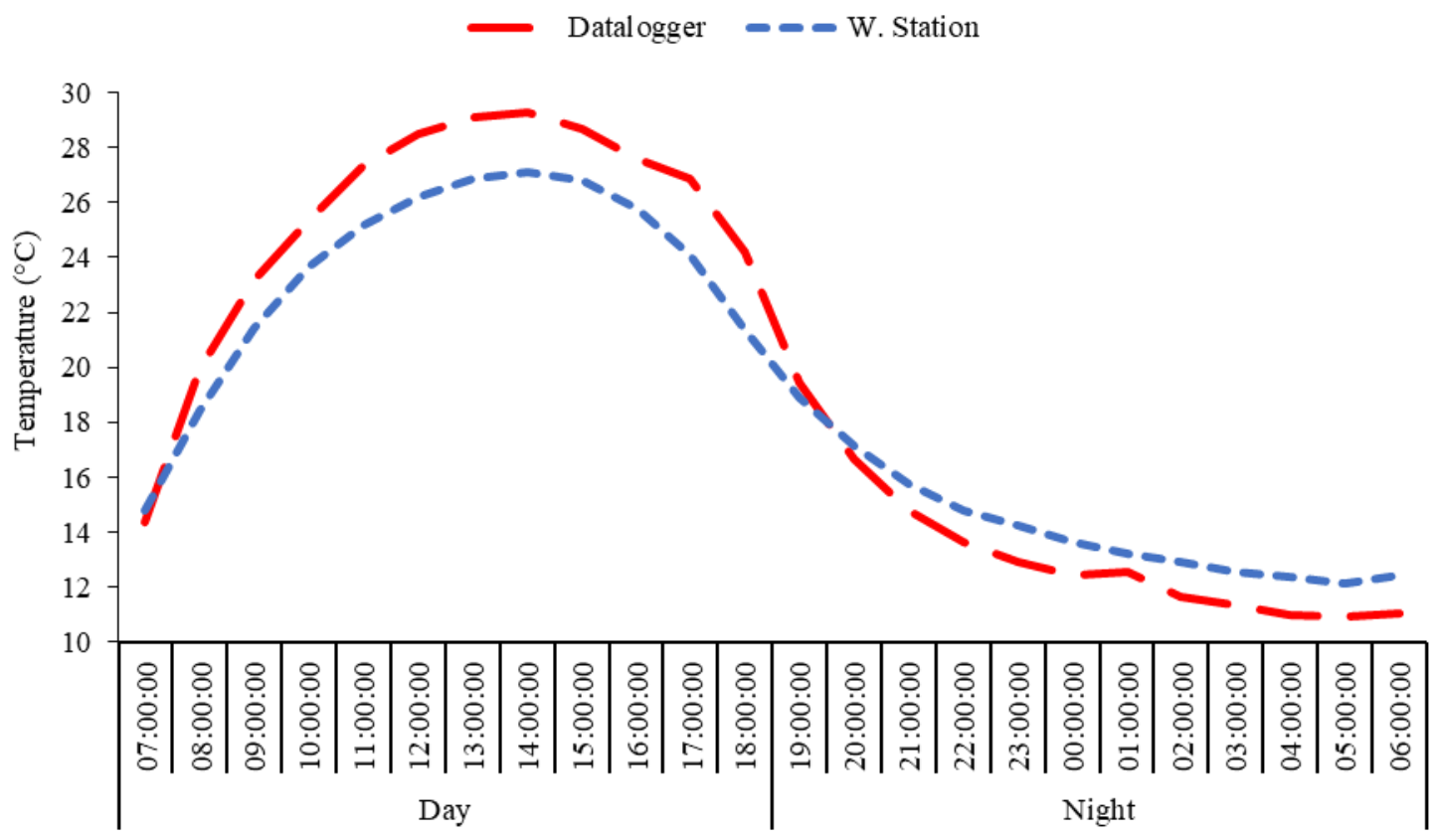

Figure 5. Average hourly temperature recorded by the datalogger LCD-520 and the weather station Block 910-CIANO from February 4 to May 5, 2020, at the Norman E. Borlaug Experimental Station in the Yaqui Valley, Sonora, Mexico.

In our study, the same phenomenon was observed between the digital sensor and the WS (Figures 1, 2, and 5). Peña Quiñoñes et al. [16] reported that for the daily AT data for $158 \mathrm{WS}$ in the Pacific Northwest in the USA, the mean radius of influence (RI) for minimum temperature $(20 \mathrm{~km})$ was significantly different from the RI calculated for maximum temperature $(23 \mathrm{~km})$. They also found high spatial and temporal variability. They indicated that the landscape and season of the year were crucial factors that define the RI of AT recorded for a particular location. In flat regions, the RI was greater than in areas where the elevation varied over a short distance, and the RI was smaller during the summer than during any of the other seasons. Their results showed that for complex terrain it was not possible to define a general RI for daily AT. In the case of our study in the Yaqui Valley, flat land defines almost the whole region. Monitoring different climatic variables in agriculture through the use of new technologies is very important, as it is the case where sensors have been developed for monitoring soil humidity and other variables throughout the crop season [17]. Results of other investigations agree with the 
Vol. 06, No. 06; 2021

ISSN: $2456-8643$

usefulness of sensor technology as a tool to economize fertilizer, reduce the environmental impact, and contribute to the cost effectiveness of wheat production [18].

\section{CONCLUSIONS}

Comparison of air temperature data obtained from the weather station (WS) and the sensor located within the wheat plot, showed significant differences between the mean of both devices. The minimum temperature recorded by the datalogger was $1.2^{\circ} \mathrm{C}$ and $0.76^{\circ} \mathrm{C}$ below the range shown by the WS, while the maximum temperature recorded by the datalogger was $1.42^{\circ} \mathrm{C}$ and $5.39^{\circ} \mathrm{C}$ above the range shown by the WS. The overall average temperature recorded by the datalogger was $0.44^{\circ} \mathrm{C}$ higher than the WS, and it also recorded 122 more cold units more than the WS.

\section{REFERENCES}

[1] Salisbury FB. y Ross CW. 2000. Fisiología de las plantas. Ediciones Thomson-Paraninfo. España. $756 \mathrm{p}$.

[2] Vera-Ramos CA, Barbosa-Jaimes JE, Pabón-González DC. 2015. Plataforma meteorológica de bajo costo basada en tecnología ZigBee. Revista Colombiana de Tecnologías de Avanzada 1(25):1-7. doi: 10.24054/16927257.v25.n25.2015.2371.

[3] Whiteman CD, Hubbe JM, and Shaw WJ. 2000. Evaluation of an inexpensive temperature datalogger for meteorological applications. Journal of Atmospheric and Oceanic Technology 17(1):77-81. doi: https://doi.org/10.1175/1520-0426(2000)017 $<0077$ :EOAITD $>2.0 . \mathrm{CO} ; 2$.

[4] Measurement Computing. 2015. USB-500/600 Series Low-Cost Data Loggers and Accessories. Norton, Massachusetts, USA.

[5] Medina García G, Grageda Grageda J, Ruiz Corral JA, y Báez González AD. 2009. Uso de estaciones meteorológicas en la agricultura. INIFAP, Centro de Investigación Regional Norte Centro, Campo Experimental Zacatecas. Folleto Técnico No. 50. Zacatecas, México. $19 \mathrm{p}$.

[6] CESAVESON-SIAFESON. 2016. Red de Estaciones Meteorológicas Automatizadas de Sonora. Hermosillo, Sonora, México.

[7] Agricien. 2020. La importancia de las variables meteorológicas para el adecuado manejo agronómico en el cultivo de arroz. San José, Costa Rica. https://www.agricien.com/blog/2020/1/17/la-importancia-de-las-variables-meteorolgicaspara-el-adecuado-manejo-agronmico-enel-cultivo-de-arroz. Consulted on August 20, 2021.

[8] Magrin GO, Díaz RA, Rebella CM, Del Santo C y Rodríguez R. 1991. Simulación del crecimiento y desarrollo del trigo en la Argentina y la necesidad de información meteorológica de entrada. CONGREMET. Buenos Aires, Argentina.

[9] Rebella CM y Díaz R. 1984. Tendencia de lluvias y rendimiento de maíz en el área maicera típica argentina. III Congreso Nacional del Maíz. Pergamino, Provincia de Buenos Aires, Argentina.

[10] Rebella C, Carballo S, Hartmann T y Mercuri P. 1999. Evento NIÑO 1997-98. Utilización de información satelital en la evaluación del impacto de las inundaciones sobre las producciones agropecuarias y forestales. Información espacial para la evaluación de las 
inundaciones del Evento Niño 97/98, Fascículo \#2 de la serie: "La CONAE y el aprovechamiento de la información espacial".

[11] Fernández P, Roby H, Fornero L y Maza J. 1987. Red hidrometeorológica telemétrica en Mendoza-Argentina: un año de experiencias e investigaciones. Centro Regional Andino. Mendoza, Provincia de Mendoza, Argentina.

[12] Elinger M. 1990. Sistema de información y alerta hidrológico para la cuenca del Río de la Plata: una experiencia en cooperación regional. Centro de Investigaciones Hidrológicas Ezeiza. Buenos Aires, Argentina.

[13] Sun B, Baker B, Karl T, and Gifford M. 2005. A comparative study of ASOS and USCRN temperature measurements. Journal of Atmospheric and Oceanic Technology 22:679-686.

[14] Gattinoni N, Boca T, Rebella C, y Di Bella C. 2011. Comparación entre observaciones meteorológicas obtenidas de estaciones convencionales y automáticas a partir de la estimación de parámetros estadísticos. Revista Investigaciones Agropecuarias (Argentina) 37(1):75-85.

[15] Peña Quiñones AJ, Hoogenboom G, Salazar Gutiérrez MR, Stöckle C, Keller M. 2020. Comparison of air temperature measured in a vineyard canopy and at a standard weather station. PLoS ONE 15(6):e0234436. https://doi.org/10.1371/journal.pone. 0234436.

[16] Peña Quiñones AJ, Chaves Cordoba B, Salazar Gutierrez MR, Keller M, and Hoogenboom G. 2019. Radius of influence of air temperature from automated weather stations installed in complex terrain. Theoretical and Applied Climatology 137:1957-1973. https://doi.org/10.1007/s00704-018-2717-9.

[17] Flores-Medina M, Flores-García F, Velasco-Martínez V, González-Cervantes G, JuradoZamarripa F. 2015. Monitoreo de humedad en suelo a través de red inalámbrica de sensores. Tecnología y Ciencias del Agua 6(5):75-88.

[18] Santillano-Cázares J, López-López A, Ortiz-Monasterio I, Raun WR. 2013. Uso de sensores ópticos para la fertilización de trigo (Triticum aestivum L.). Terra Latinoamericana 31(2):95-103. 